\title{
Gold(I) Fluorohalides: Theory and Experiment
}

\author{
Miguel Baya, ${ }^{[a]}$ Alberto Pérez-Bitrián, ${ }^{[a]}$ Sonia Martínez-Salvador, ${ }^{[a]}$ José M. Casas, ${ }^{[a]}$ \\ Babil Menjón, ${ }^{*[a]}$ and Jesús Orduna ${ }^{[b]}$
}

Dedicated to Prof. Dr. Elena Lalinde on the occasion of her 60th birthday

\begin{abstract}
The anionic trifluoromethylgold $(\mathrm{I})$ derivatives $\left[\mathrm{CF}_{3} \mathrm{AuX}\right]^{-}$, which have been prepared and isolated as their $\left[\mathrm{PPh}_{4}\right]^{+}$salts in good yield, undergo thermally induced difluorocarbene extrusion in the gas phase, giving rise to the mixed gold(I) fluorohalide complexes [F-Au$\mathrm{X}^{-}(\mathrm{X}=\mathrm{Cl}, \mathrm{Br}, \mathrm{I})$. These triatomic species have been detected by tandem mass spectrometry (MS2) experiments and their properties have been analyzed by DFT methods. The $\mathrm{CF}_{2}$ extrusion mechanism from the $\mathrm{Au}-\mathrm{CF}_{3}$ moiety serves as a model for the $\mathrm{CF}_{2}$ insertion into the $\mathrm{Au}-\mathrm{F}$ bond, since both reactivity channels are connected by the microreversibility principle.
\end{abstract}

Gold halides are simple chemical species of great theoretical and practical importance. ${ }^{[1]}$ The binary halides $\mathrm{AuX}, \mathrm{AuX}_{2}, \mathrm{AuX}_{3}$, and $\mathrm{AuF}_{5}$ exhibit quite different properties when associated in the condensed phase or as single molecules, ${ }^{[2]}$ either in the gas phase or trapped in inert matrices. ${ }^{[3,4]}$ Thus, genuine gold(II) chloride, $\mathrm{AuCl}_{2}$, has only been detected in the gas phase, ${ }^{[5]}$ whereas a solid with identical stoichiometry is, in fact, a mixed-valence species best formulated as $\mathrm{Au}^{\prime}\left[\mathrm{Au}^{\prime \prime \prime} \mathrm{Cl}_{4}\right]^{\left[{ }^{[6]}\right.}$ Moreover, the instability of gold(I) fluoride, AuF, in the condensed phase seems to derive from intermolecular processes leading to disproportionation into $\mathrm{Au}^{0}$ and $\mathrm{AuF}_{3}$ rather than from intrinsic thermodynamic reasons. ${ }^{[7,8]}$

On the whole and despite intensive research on the subject, gold fluorides still today remain challenging and rare species; especially those with the metal in low oxidation state ${ }^{[9]}$ A few ligand-supported gold(I) fluorides stabilized by neutral donors are currently known. Thus, the AuF moiety is known to form loose complexes with noble gases, $\mathrm{FAuNg}(\mathrm{Ng}=\mathrm{Ne}, \mathrm{Ar}, \mathrm{Kr}$, $\mathrm{Xe}),{ }^{[3,10]}$ and much more robust complexes with $\mathrm{NHC}$ ligands

[a] Dr. M. Baya, A. Pérez-Bitrián, Dr. S. Martínez-Salvador, Dr. J. M. Casas, Dr. B. Menjón

Instituto de Síntesis Química y Catálisis Homogénea (iSQCH)

CSIC-Universidad de Zaragoza

C/ Pedro Cerbuna 12, 50009 Zaragoza (Spain)

E-mail:menjon@unizar.es

[b] Dr. J. Orduna

Instituto de Ciencia de Materiales de Aragón (ICMA)

CSIC-Universidad de Zaragoza

C/ Pedro Cerbuna 12, 50009 Zaragoza (Spain)

$\square$ Supporting information and the ORCID identification number(s) for the au-

(iD thor(s) of this article can be found under:

http://dx.doi.org/10.1002/chem.201605655. that enable their isolation in the condensed phase: $\left[\{(\mathrm{NHC}) \mathrm{Au}\}_{n}(\mu-\mathrm{F})\right]^{(n-1)+}(n=1$ or $2 ; \mathrm{NHC}=1,3$-bis(2,6-diisopropylphenyl)-4,5-dihydroimidazol-2-ylidene). ${ }^{[1]}$ To the best of our knowledge, however, no anionic gold(I) fluoride derivative is currently known apart from the symmetric $\left[\mathrm{AuF}_{2}\right]^{-}$complex recently detected by Rijs and O'Hair in the sequential decomposition of $\left[\mathrm{Au}(\mathrm{OAc})_{2}\right]^{-}$in the gas phase $\left(\mathrm{OAc}^{\mathrm{F}}=\mathrm{CF}_{3} \mathrm{CO}_{2}\right){ }^{\left[{ }^{[12]}\right.}$

Herein we report the experimental detection of the whole series of mixed gold(I) fluorohalides $[\mathrm{F}-\mathrm{Au}-\mathrm{X}]^{-}(\mathrm{X}=\mathrm{Cl}, \mathrm{Br}, \mathrm{I})$ in the gas phase, together with their optimized equilibrium structures and their calculated stabilities. The mechanism of $\mathrm{CF}_{2}$ insertion into the $\mathrm{Au}-\mathrm{F}$ bond to give a $\mathrm{CF}_{3}$ group offers new insight into the relation and mutual transformation of these fundamental $C_{1}$ fluorocarbon units.

The trifluoromethylgold(I) derivatives $\left[\mathrm{PPh}_{4}\right]\left[\mathrm{CF}_{3} \mathrm{AuX}\right]$ (1-3) are obtained and isolated as pure substances by the procedure used to prepare the bromo derivative, ${ }^{[13]}$ which involves replacing the highly labile $\mathrm{CO}$ ligand in the gold carbonyl derivative $\mathrm{CF}_{3} \mathrm{AuCO}^{[14]}$ with the corresponding halide (Scheme 1). ${ }^{[15]}$

$$
\begin{aligned}
& \mathrm{CF}_{3} \mathrm{AuCO}+\mathrm{X}^{-} \underset{-\mathrm{CO}}{\longrightarrow} {\left[\mathrm{CF}_{3} \mathrm{AuX}\right]^{-} } \\
& \underline{\mathrm{X}} \mid \begin{array}{llll}
\mathrm{Cl} & \mathrm{Br} & \mathrm{I} \\
\hline \mathbf{1} & \mathbf{2} & 3
\end{array}
\end{aligned}
$$

Scheme 1. Method to synthesize the organogold(I) derivatives 1-3 (see the Supporting Information for details). In all cases the cation is $\left[\mathrm{PPh}_{4}\right]^{+}$.

Geometry optimizations of the mixed $\left[\mathrm{CF}_{3} \mathrm{AuX}\right]^{-}$derivatives at the DFT/M06 level of calculation yield linear structures (Figure 1) with the geometric parameters given in Table 1. The optimized geometry of the $\left[\mathrm{CF}_{3} \mathrm{AuBr}\right]^{-}$anion in the gas phase shows reasonable agreement with that experimentally established for compound $\mathbf{2}$ in the solid state (X-ray diffraction). ${ }^{[13]}$ The $\mathrm{Au}-\mathrm{CF}_{3}$ distance shows little variation with the halide going from chlorine (206.1 pm) to iodine (208.8 pm), and the $\mathrm{Au}-\mathrm{X}$ distances are just marginally longer than those calculated for the symmetric halides $\left[\mathrm{AuX}_{2}\right]^{-}$(Table 1; Supporting Information, Table S1). In the ${ }^{19} \mathrm{~F}$ NMR spectra of compounds $\mathbf{1 - 3}$, the signal corresponding to the $\mathrm{CF}_{3}$ group suffers a steady downfield shift with increasing electronegativity of the halide ligand: $\mathrm{I}<\mathrm{Br}<\mathrm{Cl}$ (Supporting Information, Figure S1). This means that the $\mathrm{F}$ atoms are deshielded in the same order.

The mononuclear organogold(I) halides 1-3 are thermally stable compounds. To the best of our knowledge, no related 
$\left[\mathrm{CH}_{3} \mathrm{AuX}\right]^{-}$species have been obtained yet in the condensed phase, and only recently has the heavier $\left[\mathrm{CH}_{3} \mathrm{Aul}\right]^{-}$derivative been detected to arise by oxidative addition of $\mathrm{I}-\mathrm{CH}_{3}$ to the bare $\mathrm{Au}^{-}$anion in the gas phase. ${ }^{[16]} \mathrm{A}$ related organocopper(I) derivative, $\left[\mathrm{CF}_{3} \mathrm{Cul}\right]^{-}$, was proposed as a key intermediate in $\mathrm{Cu}$-assisted arene trifluoromethylation processes, but it was not detected. ${ }^{[17]}$ Compounds $\mathbf{1 - 3}$ show reasonable stability towards ligand scrambling that might otherwise lead to the symmetric species $\left[\mathrm{CF}_{3} \mathrm{AuCF}_{3}\right]^{-}$and $\left[\mathrm{AuX}_{2}\right]^{-}$. In fact, no such rearrangement was experimentally observed to occur in solution at room temperature. ${ }^{[18]}$ Moreover, given their anionic nature, compounds 1-3 are ideal species for mass-spectrometry studies, which should provide valuable information on fundamental processes taking place at the unimolecular level. ${ }^{[19]}$

Negatively charged $\left[\mathrm{CF}_{3} \mathrm{AuX}\right]^{-}$complexes are efficiently transferred to the gas-phase by electrospray ionization (ESI) techniques starting from room-temperature $\mathrm{CH}_{2} \mathrm{Cl}_{2} / \mathrm{MeOH}$ solutions of the pure compounds $\mathbf{1 - 3}$. Their standard MS show no

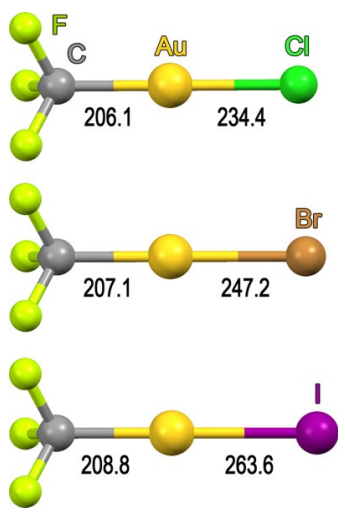

Figure 1. Geometries of the anionic $\left[\mathrm{CF}_{3} \mathrm{AuX}\right]^{-}$derivatives optimized at the DFT/M06 level with relevant structural parameters indicated (see Table 1). sign of ligand scrambling. Upon collision-induced activation of mass-selected $\left[\mathrm{CF}_{3} \mathrm{AuX}\right]^{-}$ions, the mixed $[\mathrm{F}-\mathrm{Au}-\mathrm{X}]^{-}$ions are formed and clearly detected in all three cases (Figure 2, Scheme 2). These experimental conditions preclude side-reactions, such as ligand scrambling and/or disproportionation that might hinder the preparation of the $[\mathrm{F}-\mathrm{Au}-\mathrm{X}]^{-}$species in the condensed phase. Halide dissociation (Scheme $2 \mathrm{~b}$ ) is a competing process that is also observed to occur in all cases (Supporting Information, Figures S2-S4). Calculated $\mathrm{Au}-\mathrm{X}$ bond dissociated energies $\left[\mathrm{kcalmol}{ }^{-1}\right]$ in the $\left[\mathrm{CF}_{3} \mathrm{AuX}\right]^{-} \mathrm{com}-$ plexes are as follows: 68.9 (Cl) $>65.7(\mathrm{Br})>63.7(\mathrm{l})$.
Table 1. Interatomic distances [pm] in the equilibrium structures obtained for the linear $\left[\mathrm{CF}_{3} \mathrm{AuX}\right]^{-}$and $[\mathrm{FAuX}]^{-}$anions at the DFT/M06 level of calculation. ${ }^{[a]}$

\begin{tabular}{|lcccccc} 
& \multicolumn{2}{c}{$\left[\mathrm{CF}_{3} \mathrm{AuX}\right]^{-}$} & \multicolumn{2}{c}{$[\mathrm{FAuX}]^{-}$} & $\left.[\mathrm{AuX}]_{2}\right]^{-}$ & $\mathrm{AuX}{ }^{[\mathrm{b}]}$ \\
\hline $\mathrm{X}$ & $\mathrm{Au}-\mathrm{C}^{[\mathrm{cc}}$ & $\mathrm{Au}-\mathrm{X}$ & $\mathrm{Au}-\mathrm{F}^{[\mathrm{d}]}$ & $\mathrm{Au}-\mathrm{X}$ & $\mathrm{Au}-\mathrm{X}$ & $\mathrm{Au}-\mathrm{X}$ \\
$\mathrm{Cl}$ & 206.1 & 234.4 & 201.3 & 229.7 & 231.8 & 222.6 \\
$\mathrm{Br}$ & $207.1^{[\mathrm{e}]}$ & $247.2^{[\mathrm{e}]}$ & 201.9 & 242.1 & 244.7 & 233.9 \\
$\mathrm{I}$ & 208.8 & 263.6 & 202.9 & 257.3 & 261.7 & 250.6 \\
\hline
\end{tabular}

[a] Data corresponding to symmetric $\left[\mathrm{AuX}_{2}\right]^{-}$anions and diatomic AuX molecules are also included for comparison. All the triatomic species are exactly linear, as are the $\left[\mathrm{CF}_{3} \mathrm{AuX}\right]^{-}$anions. [b] Values taken from Ref. [21]. [c] Similar $\mathrm{Au}-\mathrm{C}$ distances were found in the crystal structures of the homoleptic salts $\left[\mathrm{N}\left(\mathrm{PPh}_{3}\right)_{2}\right]\left[\mathrm{Au}\left(\mathrm{CF}_{3}\right)_{2}\right](206.5(6) \mathrm{pm})^{[36]}$ and $\left[\mathrm{PPh}_{4}\right]\left[\mathrm{Au}\left(\mathrm{CF}_{3}\right)_{2}\right]$ $(203.3(2) \mathrm{pm}){ }^{[14 a]}[\mathrm{d}] \mathrm{In}$ the free diatomic AuF molecule, $\mathrm{Au}-\mathrm{F}=$ $191.84 \mathrm{pm}^{[8]}$ [e] Experimental interatomic distances in the crystal of $\left[\mathrm{PPh}_{4}\right]\left[\mathrm{CF}_{3} \mathrm{AuBr}\right]$ are as follows: $\mathrm{Au}-\mathrm{C}$ 211.9(5) pm and $\mathrm{Au}-\mathrm{Br}$ 240.5(1) pm. ${ }^{[13]}$
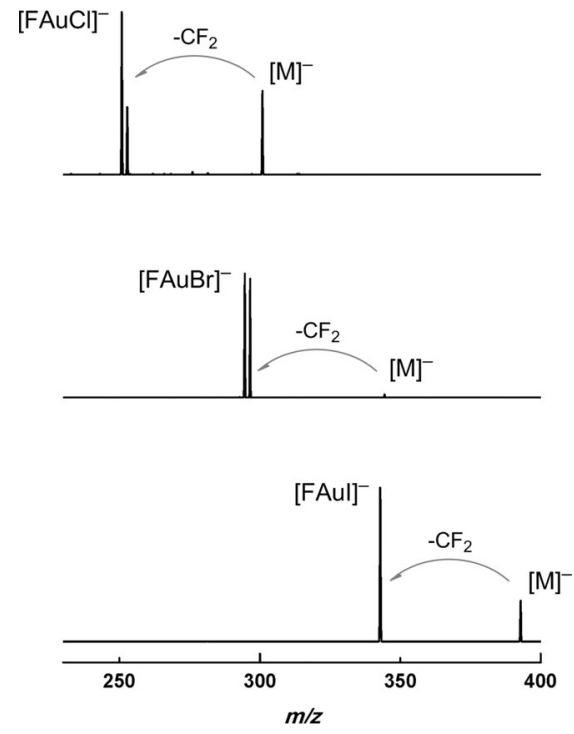

Figure 2. Detection of the mixed $[\mathrm{FAuX}]^{-}$anions $(\mathrm{X}=\mathrm{Cl}, \mathrm{Br}, \mathrm{I})$ formed by collision-induced dissociation of the corresponding $\left[\mathrm{CF}_{3} \mathrm{AuX}\right]^{-}$species (labeled $[\mathrm{M}]^{-}$) in quadrupole ion-trap $\mathrm{MS}^{2}$ experiments.

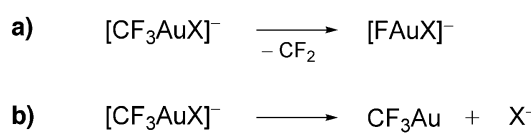

Scheme 2. Competing dissociation processes undergone by the $\left[\mathrm{CF}_{3} \mathrm{AuX}\right]^{-}$ anions in the gas phase.

Geometry optimizations of the triatomic $[\mathrm{F}-\mathrm{Au}-\mathrm{X}]^{-}$anions were performed to find out their structural arrangement and the results were characterized vibrationally (see the Supporting Information for details). All three anions show a linear structure with $C_{\infty v}$ symmetry (Figure 3) and the interatomic distances given in Table 1. Taking the neutral diatomic AuF molecule as a reference (Au-F $191.84 \mathrm{pm}){ }^{[8]}$ the coordination of an additional $\mathrm{X}^{-}$ligand results in elongation of the $\mathrm{Au}-\mathrm{F}$ bond by $\mathrm{ca} .10 \mathrm{pm}^{[20]}$
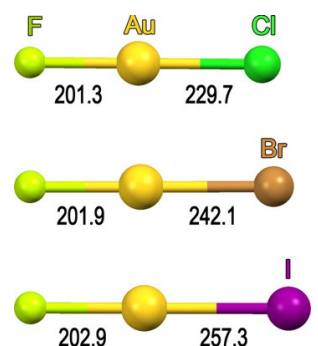

Figure 3. Geometries of the mixed [FAuX] $]^{-}$anions optimized at the DFT/M06 level with relevant structural parameters indicated (see Table 1). thus becoming comparable to the bond length observed in the neutral FAu(NHC) complex (Au-F 202.8(8) pm). ${ }^{[11 b]}$ In the same way, the $\mathrm{Au}-\mathrm{X}$ bond is elongated by a similar amount with respect to the diatomic AuX molecules ${ }^{[21]}$ upon $\mathrm{F}^{-}$coordination. Addition of $\mathrm{F}^{-}$to the heavier gold halides, AuX, was precisely the method originally suggested by Schwerdtfeger to prepare the mixed $[\mathrm{F}-\mathrm{Au}-\mathrm{X}]^{-}$derivatives. ${ }^{[22]}$ However, we are not aware that this method has yielded any positive results so far.

In the absence of external acids, ${ }^{[23]}$ decomposition of trifluoromethyl metal derivatives is commonly assumed to follow the tautomeric equilibrium shown in Scheme $3 \mathrm{a}$ as identified by 
a)

$$
\begin{aligned}
\text { a) } & \mathrm{F}-[\mathrm{M}]=\mathrm{CF}_{2} \\
\text { b) } \quad \mathrm{F}-[\mathrm{Ru}]=\mathrm{CF}_{2}+\mathrm{CO} & \longrightarrow \mathrm{CF}_{3} \\
& \longrightarrow \mathrm{OC}-[\mathrm{Ru}]-\mathrm{CF}_{3}
\end{aligned}
$$

Scheme 3. Tautomeric equilibrium applying to trifluoromethyl metal derivatives: a) in general, and b) evidenced in ruthenium(II) systems; $[\mathrm{Ru}]=\left(\mathrm{R}_{3} \mathrm{P}\right) \mathrm{RuH}(\mathrm{CO})$ and $\mathrm{PR}_{3}=\mathrm{PiPr}_{3}, \mathrm{PMetBu}_{2}{ }^{[24]}$

Caulton in organoruthenium systems (Scheme 3 b). ${ }^{[24]}$ This mechanism was also suggested to apply to the decomposition of $\left[\mathrm{CF}_{3} \mathrm{MR}\right]^{-}$ions in the gas phase $\left(\mathrm{M}=\mathrm{Cu}, \mathrm{Ag}, \mathrm{Au} ; \mathrm{R}=\mathrm{F}, \mathrm{CF}_{3}\right.$, $\left.O A C^{F}\right){ }^{[12]}$ With regard to our own system, this mechanism is commented on in detail in the Supporting Information.

We have now found a lower-energy path for the $\left[\mathrm{CF}_{3} \mathrm{AuX}\right]^{-}$ decomposition that differs from the standard mechanism as no difluorocarbene metal intermediate $[\mathrm{M}] \mathrm{CF}_{2}$ is involved. This alternative mechanism (Figure 4) comprises the following

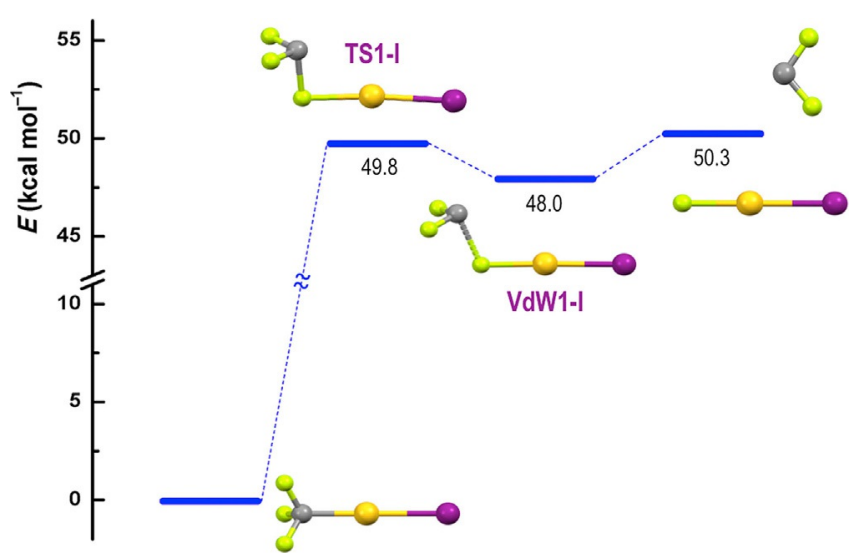

Figure 4. Energy profile of the lower-energy $\mathrm{CF}_{2}$ extrusion path from the organogold $\left[\mathrm{CF}_{3} \mathrm{Aul}\right]^{-}$derivative (see the Supporting Information, Figures S7 and $\mathrm{S} 8$ for structural details of the intermediates involved). The same but reverse profile applies to the $\mathrm{CF}_{2}$ insertion into the $\mathrm{Au}-\mathrm{F}$ bond. For color code, see Figure 1.

steps: 1) weakening of the $\mathrm{Au}-\mathrm{C}$ bond in favor of a $\mathrm{Au}-\mathrm{F}$ bond through a transient $\eta^{2}$-coordinated $\mathrm{F}_{2} \mathrm{C}-\mathrm{F}$ unit (Scheme $4 \mathrm{a})$; 2) complete loss of the $\mathrm{Au}-\mathrm{C}$ interaction in the transition state (TS1), which features an uncommon fluoridebridging $\mathrm{F}_{2} \mathrm{C}-\mathrm{F}-[\mathrm{Au}]$ unit (Scheme $4 \mathrm{~b}$ ); and 3) release of the unsaturated $: \mathrm{CF}_{2}$ unit from the ensuing van der Waals complex (VdW1) that leaves the triatomic $[\mathrm{F}-\mathrm{Au}-\mathrm{X}]^{-}$species. The last step involves just a small dissociation threshold of $<3 \mathrm{kcal}$ $\mathrm{mol}^{-1}$.

Owing to the microreversibility principle, the mechanism just discussed also applies to the : $\mathrm{CF}_{2}$ insertion into the $\mathrm{Au}-\mathrm{F}$ bond. Thus, the interaction of free $: \mathrm{CF}_{2}$ with the electron density of the $\mathrm{F}$ ligand results in slight stabilization and entails little structural modification in any of the moieties involved. This interaction confirms the inherently ambiphilic character of the singlet fluorinated divalent carbon atom that bears both a lone pair and an empty $p$ orbital, the latter being involved in partial $F(p) \rightarrow C(p) \pi$-donation. ${ }^{[25-29]}$ The strengthening of this a)<smiles></smiles>

b)<smiles>CCC#[W]C(F)(F)F</smiles>

(TS1) c)<smiles>FC1[IH]C1F</smiles>

d)

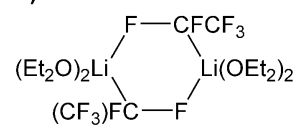

Scheme 4. Structural patterns involving $\mathrm{C}-\mathrm{F}$...M interactions: a) transient species formed upon thermal excitation of $\left[\mathrm{CF}_{3} \mathrm{AuX}\right]^{-} ;$b) transition state in the $\mathrm{CF}_{2}$ extrusion/insertion path given in Figure 4 (see the Supporting Information, Figure S7 for structural details); c) global minimum calculated for $\mathrm{LiCF}_{3}$ in the gas phase; ; $\left.{ }^{[33]} \mathrm{d}\right)$ central core of the $\mathrm{Li}\left(\mathrm{CF}_{2} \mathrm{CF}_{3}\right) \cdot 2 \mathrm{Et}_{2} \mathrm{O}$ dimer in the crystal. ${ }^{[32]}$.

$\mathrm{F}_{2} \mathrm{C} \ldots \mathrm{F}-[\mathrm{Au}]$ interaction in the initial van der Waals complex leads to significant elongation of the $A u-F$ bond, which, in the transition state ( $\mathrm{Au}-\mathrm{F}$ ca. $215 \mathrm{pm}$; Scheme $4 \mathrm{~b}$ ), is substantially longer than in the fluoride-bridged dinuclear complex $\left[\{(\mathrm{NHC}) \mathrm{Au}\}_{2}(\mu-\mathrm{F})\right]\left[\mathrm{BF}_{4}\right]\left(\mathrm{Au}-\mathrm{F}\right.$ 206.0(1) pm). ${ }^{[11 \mathrm{a}]}$ The metallotropic shift from $\mathrm{F}$ to $\mathrm{C}$ through a transient $\mathrm{Au}\left(\eta^{2}-\mathrm{F}-\mathrm{CF}_{2}\right)$ species (Scheme $4 a$ ) leads to the final insertion product $\left[\mathrm{CF}_{3} \mathrm{AuX}\right]^{-}$. Along the reaction path, the carbon atom gradually increases the number of substituents from two in the initial carbene to three in the transition state and four in the final product. The global insertion process takes place in an almost barrierless way and results in large stabilization, so it might be experimentally feasible. ${ }^{[30]}$

It is worth noting that the structures of both the transition state and the transient species referred to in the mechanism just discussed find support in the chemistry of lithium carbenoids. ${ }^{[31]}$ Thus, the bridging role of the $\mathrm{F}-\mathrm{C}$ unit was substantiated in the crystal structure of the $\mathrm{Li}\left(\mathrm{CF}_{2} \mathrm{CF}_{3}\right) \cdot 2 \mathrm{Et}_{2} \mathrm{O}$ dimer (Scheme $4 d){ }^{\left[{ }^{[32]}\right.}$ while a $\mathrm{Li}\left(\eta^{2}-\mathrm{F}-\mathrm{CF}_{2}\right)$ interaction was found to be the global minimum for $\mathrm{LiCF}_{3}$ in the gas phase (Scheme $4 \mathrm{c})^{[33]}$ Both perfluoroalkyl lithium systems are known to release the corresponding fluorinated carbene upon LiF elimination in a sometimes violent process ${ }^{[34]}$ Considering that our gold systems also release $\mathrm{CF}_{2}$ without the need of any actual metal carbene intermediate, they can properly be termed gold carbenoids. ${ }^{[35]}$

In summary, the anionic organogold $(\mathrm{I})\left[\mathrm{CF}_{3} \mathrm{AuX}\right]^{-}$complexes $(\mathrm{X}=\mathrm{Cl}, \mathrm{Br}, \mathrm{I})$ are found to perform as gold carbenoids, since they undergo $\mathrm{CF}_{2}$ extrusion in the gas phase affording the mixed gold(I) fluorohalide $[\mathrm{F}-\mathrm{Au}-\mathrm{X}]^{-}$complexes. The experimental detection of these simple, triatomic species demonstrates that AuF can indeed be stabilized by heavier-halide coordination, as formerly suggested by Schwerdtfeger. ${ }^{[22]}$ These species might, however, be difficult to isolate in the condensed phase unless facile ligand scrambling is precluded. An unconventional $\mathrm{CF}_{2}$ insertion/extrusion mechanism not involving any metal carbene intermediate has been identified, which might be relevant to difluoromethylation processes mediated by late transition metals. 


\section{Acknowledgements}

This work was supported by the Spanish MINECO/FEDER (Project CTQ2015-67461-P), and the Gobierno de Aragón and Fondo Social Europeo (Grupo Consolidado E21: Química Inorgánica y de los Compuestos Organometálicos). The Instituto de Biocomputación y Física de Sistemas Complejos (BIFI) and the Centro de Supercomputación de Galicia (CESGA) are greatfully acknowledged for generous allocation of computational resources. A.P.B. thanks the Spanish Ministerio de Educación, Cultura y Deporte for a grant (FPU15/03940).

Keywords: difluorocarbene - gold carbenoids - gold fluorides • organogold compounds $\cdot$ trifluoromethyl compounds

[1] H. Raubenheimer, S. Cronje, in Gold: Progress in Chemistry, Biochemistry and Technology (Ed.: H. Schmidbaur), John Wiley \& Sons, Chichester (UK), 1999, Ch. 16, pp. 557-632.

[2] M. Hargittai, Acc. Chem. Res. 2009, 42, 453; A. Schulz, M. Hargittai, Chem. Eur. J. 2001, 7, 3657; M. Hargittai, Chem. Rev. 2000, 100, 2233.

[3] a) X. Wang, L. Andrews, F. Brosi, S. Riedel, Chem. Eur. J. 2013, 19, 1397; b) X. Wang, L. Andrews, K. Willmann, F. Brosi, S. Riedel, Angew. Chem. Int. Ed. 2012, 51, 10628; Angew. Chem. 2012, 124, 10780.

[4] a) I. J. Blackmore, A. J. Bridgeman, N. Harris, M. A. Holdaway, J. F. Rooms, E. L. Thompson, N. A. Young, Angew. Chem. Int. Ed. 2005, 44, 6746 Angew. Chem. 2005, 117, 6904; b) B. Réffy, M. Kolonits, A. Schulz, T. M. Klapötke, M. Hargittai, J. Am. Chem. Soc. 2000, 122, 3127.

[5] D. Schröder, R. Brown, P. Schwerdtfeger, X.-B. Wang, X. Yang, L.-S. Wang, H. Schwarz, Angew. Chem. Int. Ed. 2003, 42, 311; Angew. Chem. 2003, $115,323$.

[6] D. B. dell'Amico, F. Calderazzo, F. Marchetti, S. Merlino, J. Chem. Soc. Dalton Trans. 1982, 2257.

[7] a) P. Schwerdtfeger, J. S. McFeaters, M. J. Liddell, J. Hrušák, H. Schwarz, J. Chem. Phys. 1995, 103, 245; b) D. Schröder, J. Hrušák, I. C. TornieporthOetting, T. M. Klapötke, H. Schwarz, Angew. Chem. Int. Ed. Engl. 1994, 33, 212; Angew. Chem. 1994, 106, 223.

[8] a) T. Okabayashi, Y. Nakaoka, E. Yamazaki, M. Tanimoto, Chem. Phys. Lett. 2002, 366, 406; b) C. J. Evans, M. C. L. Gerry, J. Am. Chem. Soc. 2000, $122,1560$.

[9] a) F. Mohr, Gold Bull. 2004, 37, 164; b) N. Bartlett, Gold Bull. 1998, 31, 22; c) B. G. Müller, Angew. Chem. Int. Ed. Engl. 1987, 26, 1081; Angew. Chem. 1987, 99, 1120.

[10] a) S. A. Cooke, M. C. L. Gerry, J. Am. Chem. Soc. 2004, 126, 17000; b) J. M. Thomas, N. R. Walker, S. A. Cooke, M. C. L. Gerry, J. Am. Chem. Soc. 2004, 126, 1235; c) C. J. Evans, D. S. Rubinoff, M. C. L. Gerry, Phys. Chem. Chem. Phys. 2000, 2, 3943.

[11] a) C. M. Wyss, B. K. Tate, J. Bacsa, M. Wieliczko, J. P. Sadighi, Polyhedron 2014, 84, 87; b) D. S. Laitar, P. Müller, T. G. Gray, J. P. Sadighi, Organometallics 2005, 24, 4503.

[12] N. J. Rijs, R. A. J. O'Hair, Dalton Trans. 2012, 41, 3395.

[13] S. Martínez-Salvador, L. R. Falvello, A. Martín, B. Menjón, Chem. Sci. 2015, 6, 5506 .

[14] a) S. Martínez-Salvador, L. R. Falvello, A. Martín, B. Menjón, Chem. Eur. J. 2013, 19, 14540; b) S. Martínez-Salvador, J. Forniés, A. Martín, B. Menjón, Angew. Chem. Int. Ed. 2011, 50, 6571; Angew. Chem. 2011, 123, 6701.

[15] Our attempts to prepare the fluoro derivative $\left[\mathrm{CF}_{3} \mathrm{AuF}\right]^{-}$in the condensed phase failed thus far. This organogold fluoride complex, however, was formed in the gas phase by collision-induced fragmentation of the homoleptic $\left[\mathrm{CF}_{3} \mathrm{AuCF}_{3}\right]^{-}$anion (see Ref. [12]).

[16] S. Muramatsu, K. Koyasu, T. Tsukuda, J. Phys. Chem. A 2016, 120, 957.

[17] G. E. Carr, R. D. Chambers, T. F. Holmes, D. G. Parker, J. Chem. Soc. Perkin Trans. 1 1988, 921.
[18] The peaks corresponding to the symmetric species $\left[\mathrm{CF}_{3} \mathrm{AuCF}_{3}\right]^{-}$and $\left[\mathrm{AuX}_{2}\right]^{-}$were absent in the mass spectra (ESI) of the mixed $\left[\mathrm{CF}_{3} \mathrm{AuX}\right]^{-}$ derivatives.

[19] a) R. A. J. O'Hair, in The Chemistry of Organogold Compounds, Vol. 1 (Eds.: Z. Rappoport, I. Marek, J. F. Liebman), Patai's Chemistry of Functional Groups, John Wiley \& Sons, Chichester, UK, 2014, Ch. 9, pp. 391 408; b) J. Roithová, D. Schröder, Coord. Chem. Rev. 2009, 253, 666.

[20] Coordination of a noble gas to the AuF molecule causes, in turn, no significant variation in the Au-F distance (see Refs. $[3,10])$.

[21] J. R. Brown, P. Schwerdtfeger, D. Schröder, H. Schwarz, J. Am. Soc. Mass Spectrom. 2002, 13, 485.

[22] P. Schwerdtfeger, P. D. W. Boyd, A. K. Burrell, W. T. Robinson, M. J. Taylor, Inorg. Chem. 1990, 29, 3593.

[23] The action of external acids on trifluoromethyl metal derivatives, $[\mathrm{M}] \mathrm{CF}_{3}$, is known to promote $\alpha$-fluoride abstraction yielding difluorocarbene metal species, $[\mathrm{M}] \mathrm{CF}_{2}$, with various degrees of stability: a) M. A. García-Monforte, S. Martínez-Salvador, B. Menjón, Eur. J. Inorg. Chem. 2012, 4945; b) R. P. Hughes, Eur. J. Inorg. Chem. 2009, 4591; c) P. J. Brothers, W. R. Roper, Chem. Rev. 1988, 88, 1293.

[24] a) D. Huang, P. R. Koren, K. Folting, E. R. Davidson, K. G. Caulton, J. Am. Chem. Soc. 2000, 122, 8916; b) D. Huang, K. G. Caulton, J. Am. Chem. Soc. $1997,119,3185$.

[25] The relatively strong Lewis acidity of singlet $\mathrm{CF}_{2}$ is clearly evidenced by its computed fluoride ion affinity (FIA) in the gas phase: $-46.0 \mathrm{kcal}$ $\mathrm{mol}^{-1}$ (see Ref. [26]). This value is in excellent agreement with the recently evaluated adiabatic gas-phase bond dissociation enthalpy of the $\left(\mathrm{CF}_{3}\right)^{-}$anion into singlet $\mathrm{CF}_{2}$ and $\mathrm{F}^{-}$at $298 \mathrm{~K}: 46.7 \mathrm{kcalmol}^{-1}$ (see Ref. [27]). Further evidence of the acidic character of $\mathrm{CF}_{2}$ is shown by its electrophilic behavior towards alkenes in cycloaddition processes (see Ref. [28]) as well as by its ability to form ylides ${ }^{-} \mathrm{CF}_{2}-\mathrm{B}^{+}$with neutral monodentate Lewis bases (B; see Ref. [29]).

[26] D. A. Dixon, D. Feller, G. Sandrone, J. Phys. Chem. A 1999, 103, 4744.

[27] G. K. S. Prakash, F. Wang, Z. Zhang, R. Haiges, M. Rahm, K. O. Christe, T. Mathew, G. A. Olah, Angew. Chem. Int. Ed. 2014, 53, 11575; Angew. Chem. 2014, 126, 11759.

[28] a) P. Pérez, J. Phys. Chem. A 2003, 107, 522; b) R. A. Moss, in Carbene Chemistry: From Fleeting Intermediates to Powerful Reagents (Ed.: G. Bertrand), Marcel Dekker, New York, 2002, Ch. 3, pp. 57-101.

[29] a) J. Zheng, J.-H. Lin, J. Cai, J.-C. Xiao, Chem. Eur. J. 2013, 19, 15261; b) R. A. Moss, L. Wang, K. Krogh-Jespersen, J. Am. Chem. Soc. 2009, 131, 2128; c) D. J. Burton, Z.-Y. Yang, W. Qiu, Chem. Rev. 1996, 96, 1641.

[30] Precedents for $\mathrm{CH}_{2}$ insertion into $\mathrm{Au}-\mathrm{Cl}$ bonds are already known: A. N. Nesmeyanov, É. G. Perevalova, E. I. Smyslova, V. P. Dyadchenko, K. I. Grandberg, Izv. Akad. Nauk SSSR Ser. Khim. 1977, 2610; Bull. Acad. Sci. USSR Div. Chem. Sci. (Engl. Transl.) 1977, 26, 2417.

[31] a) V. H. Gessner, Chem. Commun. 2016, 52, 12011; b) V. Capriati, in Contemporary Carbene Chemistry (Eds.: R. A. Moss, M. P. Doyle), John Wiley \& Sons, Hoboken, 2014, Ch. 11, pp. 325-362; c) V. Capriati, S. Florio, Chem. Eur. J. 2010, 16, 4152.

[32] B. Waerder, S. Steinhauer, B. Neumann, H.-G. Stammler, A. Mix, Y. V. Vishnevskiy, B. Hoge, N. W. Mitzel, Angew. Chem. Int. Ed. 2014, 53, 11640; Angew. Chem. 2014, 126, 11824.

[33] a) J. Kvíčala, J. Štambaský, S. Böhm, O. Paleta, J. Fluorine Chem. 2002, 113,$147 ; b$ ) a similar structural pattern was found for the potassium salt $\mathrm{KCF}_{3}$ in a modeled THF solvation environment (see Ref. [27]).

[34] a) R. D. Chambers, Fluorine in Organic Chemistry, 2nd ed., Blackwell Publishing Ltd, Oxford (UK), 2004, Ch. 6, pp. 137-161; b) D. M. Roddick, Chem. Eng. News 1997, 75(40), 6.

[35] Y. Wang, M. E. Muratore, A. M. Echavarren, Chem. Eur. J. 2015, 21, 7332.

[36] D. Zopes, S. Kremer, H. Scherer, L. Belkoura, I. Pantenburg, W. Tyrra, S. Mathur, Eur. J. Inorg. Chem. 2011, 273.

Manuscript received: December 3, 2016

Accepted Article published: December 9, 2016

Final Article published: January 12, 2017 